EXPERIMENTAL STUDY

\title{
Somatostatin analogues stimulate p27 expression and inhibit the MAP kinase pathway in pituitary tumours
}

\author{
Erika Hubina ${ }^{1,2}$, Alexandra M Nanzer ${ }^{1}$, Matthew R Hanson ${ }^{1}$, Enrica Ciccarelli ${ }^{3}$, Marco Losa ${ }^{5}$, Daniela Gaia ${ }^{3}$, \\ Mauro Papotti ${ }^{4}$, Maria Rosaria Terreni ${ }^{5}$, Sahira Khalaf ${ }^{1}$, Suzanne Jordan ${ }^{1}$, Sándor Czirják ${ }^{6}$, Zoltán Hanzély ${ }^{6}$, \\ György M Nagy ${ }^{7}$, Miklós I Góth ${ }^{2}$, Ashley B Grossman ${ }^{1}$ and Márta Korbonits ${ }^{1}$ \\ ${ }^{1}$ Department of Endocrinology, William Harvey Research Institute, Barts and the London Medical School, Queen Mary College, Charterhouse Square, \\ London EC1M 6BQ, UK, ${ }^{2}$ Division of Endocrinology, Department of Medicine, National Medical Centre, 1135 Budapest, Hungary, Departments of \\ ${ }^{3}$ Internal Medicine and ${ }^{4}$ Pathology, Ospedale Molinette, University of Turin, 10100 Turin, Italy, ${ }^{5}$ Pituitary Unit of the Department of Neurosurgery, \\ University Vita-Salute, 20132 Milan, Italy, ${ }^{6}$ National Institute of Neurosurgery, 1143 Budapest, Hungary and ${ }^{7}$ Neuroendocrine Research Laboratory, \\ Department of Human Morphology, Semmelweis University, 1095 Budapest, Hungary
}

(Correspondence should be addressed to M Korbonits; Email: m.korbonits@qmul.ac.uk)

\begin{abstract}
Objectives: Somatostatin (SST) analogues play an important role in the medical management of somatotroph pituitary adenomas and new agonists have the potential to be effective in a wider group of pituitary and other tumours. The anti-proliferative effect of SST occurs through multiple mechanisms, one of which is cell-cycle arrest, where p27, a cyclin-dependent kinase inhibitor, is an important regulator. We hypothesised that SST may upregulate p27 protein levels and downregulate the MAP kinase pathway in these tumours.

Methods: Human pituitary adenoma cells and rat pituitary cell line (GH3) were cultured and treated in vitro with octreotide and the broad-spectrum SST agonist SOM230 (pasireotide). Immunoblotting for p27 and phospho-ERK (pERK) was performed and proliferation assessed by $\left[{ }^{3} \mathrm{H}\right]$-thymidine incorporation. Histological samples from acromegalic patients treated with octreotide before surgery were immunostained for $\mathrm{p} 27$ and compared to samples from untreated patients matched for sex, age, tumour size, extension and invasiveness.

Results: We detected upregulation of p27 protein levels with SST analogue treatment in vitro in human pituitary adenoma samples. pERK1/2 was inhibited by SST analogues in both the human samples and GH3 cells. SST and its analogues inhibited the proliferation of GH3 cells. p27 immunostaining was stronger in samples from patients with longer preoperative octreotide treatment (more than 6 months) than in samples from patients with shorter treatment periods.

Conclusions: This study demonstrates that SST-mediated growth inhibition is associated with the downregulation of pERK and upregulation of p27. More potent and broader-spectrum SST analogues are likely to play an increasing role in the treatment of tumours, where the MAP kinase pathway is overactivated.
\end{abstract}

European Journal of Endocrinology 155 371-379

\section{Introduction}

Pituitary tumours are common neoplasms, with a reported prevalence of $17 \%$ in the general population (1). Somatostatin (SST) and its stable analogues are primarily used to inhibit hormone secretion of somatotroph and thyrotroph adenomas, but there are also data suggesting that they have direct effects on tumour growth. However, while SST analogues decrease cell growth and proliferation in both normal and tumour cells in various epithelial and endocrine cell types, the exact mechanisms of cell growth arrest are poorly understood. Previous studies have suggested that the inhibitory effect of SST can be either direct inhibition of cell proliferation, or indirect via inhibition of secretion of growth-inducing hormones or inhibition of angiogenesis
(2). SST acts through five high-affinity, G protein-coupled membrane receptors, which are variably expressed in both normal tissues and tumours; the analogue octreotide activates SST receptor subtype-2 (SSTR2) and to a lesser extent SSTR5, while the new SST analogue SOM230 (pasireotide) activates SSTR1, 2, 3 and 5 receptors, with varying affinity $(3,4)$.

The direct inhibition of cell proliferation by SST and its analogues may involve several signal transduction pathways including control of the MAP kinase pathway (5) and stimulation of the cyclin-dependent kinase (Cdk) inhibitor $\mathrm{p} 27^{\mathrm{Kip} 1}(6)$. Cell-cycle progression in mammalian cells requires the co-ordinated action of Cdks and cyclin complexes: p27 is a widely distributed Cdk inhibitor that has a negative influence on cell-cycle progression and it can be used as a prognostic marker in 
human malignant tumours. Overexpression of p27 leads to cell-cycle arrest (7), while lack of p27 results in pituitary adenomas in p27 'knockout' animals (8-10). We, and others, have previously shown reduced expression of p27 in a variety of pituitary adenomas (11-15), although a single study was not able to confirm this (16).

The aim of the present study was to investigate the pituitary effects of SST analogues on: (i) cell proliferation, (ii) MAP kinase activation and (iii) p27 expression using several approaches, including a pituitary cell line (for i and ii), in vitro cultured human adenomas (for ii and iii) and using histological samples from patients with acromegaly treated pre-operatively with SST analogues to study the immunohistochemical expression of p27 (iii). We believe this is the first study to show these effects in the pituitary.

\section{Methods}

\section{Cell culture}

GH3 cells The rat somatotroph cell line GH3 cells were cultured as previously described (17). The cells were plated at a density of $1 \times 10^{6}$ cells/well in six-well plates for western blotting for ERK, and $5 \times 10^{4}$ cells/well in 24-well plates for the $\left[{ }^{3} \mathrm{H}\right]$-thymidine incorporation.

Human adenomas Ten pituitary adenoma tissues (two somatotroph tumours, five non-functioning pituitary adenomas (NFPAs), one lactotroph, one corticotroph and one thyrotroph tumour) were studied for changes in p27 or phospho-ERK (pERK) expression. Patient details are shown in Table 1 . The tumours were collected fresh during surgery and all patients gave written informed consent for the protocol, which was approved by the local Institutional Review Board. Following trans-sphenoidal surgery, human pituitary adenoma cells were dispersed in vitro (18) at a density of $1 \times 10^{6}$ cells/well in six-well plates.

\section{$\left[{ }^{3} H\right]$-Thymidine incorporation}

GH3 cells were grown in media containing $2 \%$ charcoalstripped foetal calf serum and treated with various concentrations $\left(10^{-6}-10^{-12} \mathrm{M}\right)$ of SST (Sigma), octreotide and SOM230 (Novartis) and 12-phorbol 13myristate acetate (PMA) $10^{-7} \mathrm{M}$ (CN Biosciences, Nottingham, UK) for 24, 48, 72 and $96 \mathrm{~h}$ with the addition of $2 \mu \mathrm{Ci} /$ well of $\left[{ }^{3} \mathrm{H}\right]$-thymidine (Amersham) for further $6 \mathrm{~h}$ (17); $72 \mathrm{~h}$ was selected for further experiments. The cells were harvested before counting in the presence of scintillation fluid using a Microbeta 1450 $\beta$-counter (Wallac, Turku, Finland). The experiments were repeated at least three times.

\section{Immunoblotting}

Serum-starved (for $24 \mathrm{~h}$ ) human pituitary adenoma cells were treated with octreotide and SOM230 for $72 \mathrm{~h}$ or $10 \mathrm{~min}$ for the assessment of p27 protein (patients 1-5) or pERK1/2 expression (patients 6-10) respectively. Serum-starved GH3 cells were treated for $10 \mathrm{~min}$ for pERK assessment. Immunoblotting and image analysis were performed as described earlier (17). Primary antibody for p27 was used at a concentration of 1:500 (Santa Cruz, CA, USA) in TBS-Tween, $\beta$-actin at a concentration of 1:1000 (Abcam, Cambridge, UK), and anti-phosphorylated and anti-total ERK at a concentration of 1:1000 (Promega) in 5\% non-fat dry milk in TBS-Tween overnight at $4{ }^{\circ} \mathrm{C}$. After eight washes in TBS-Tween, the membranes were incubated with the secondary antibody (anti-rabbit antibody at a concentration of 1:10 000 (Dako, Glostrup, Denmark) for p2 7, pERK and total ERK; and anti-mouse antibody at a concentration of 1:10 000 (Dako) for $\beta$-actin) conjugated with horseradish peroxidase. A chemiluminescent peroxidase substrate, ECL Plus (Amersham), was applied according to the manufacturer's instructions, and the membranes were exposed briefly to X-ray film. Densitometric readings of the resulting bands were evaluated using the Scientific Imaging System (Kodak) and the

Table 1 Patient data and adenoma somatostatin receptor (SSTR) expression in human adenoma samples studied in vitro.

\begin{tabular}{|c|c|c|c|c|c|c|c|c|}
\hline Patient & Gender & $\begin{array}{c}\text { Age } \\
\text { (years) }\end{array}$ & $\begin{array}{l}\text { Diagnosis } \\
\text { (clinical and } \\
\text { histological) }\end{array}$ & $\begin{array}{l}\text { Ki-67-labelling } \\
\text { index }\end{array}$ & SSTR1 & SSTR2 & SSTR3 & SSTR5 \\
\hline 1 & Female & 27 & $\mathrm{GH}$ & 4 & + & + & + & + \\
\hline 2 & Male & 44 & NFPA & 3 & + & + & + & + \\
\hline 3 & Male & 82 & NFPA & 1.5 & - & - & + & - \\
\hline 4 & Male & 36 & NFPA & 1.6 & - & - & + & - \\
\hline 6 & Male & 60 & NFPA & 2 & - & - & + & - \\
\hline 7 & Male & 45 & $\mathrm{TSH}$ & 1.2 & + & + & - & + \\
\hline 8 & Male & 42 & $\mathrm{GH}$ & 1.0 & - & - & + & + \\
\hline 9 & Female & 36 & ACTH & 1.2 & - & + & + & - \\
\hline 10 & Female & 32 & NFPA & $\mathrm{N} / \mathrm{A}$ & - & + & + & - \\
\hline
\end{tabular}

$\mathrm{GH}$, somatotroph adenoma; NFPA, non-functioning pituitary adenoma; PRL, prolactinoma; TSH, thyrotrophinoma; ACTH, corticotrophinoma. 
ratio to total ERK or $\beta$-actin was calculated and compared to controls.

\section{Reverse transcriptase (RT)-PCR}

SSTR expression of the human pituitary samples was studied with RT-PCR. RNA extraction and RT-PCR procedures have been previously described (18). We performed an additional second DNase treatment using RNase-free DNase ( $5 \mu \mathrm{l} /$ sample; Promega) and RNA was incubated at $37^{\circ} \mathrm{C}$ for $30 \mathrm{~min}$ followed by $68{ }^{\circ} \mathrm{C}$ for 10 min. A negative control with the omission of the RT enzyme was also included. PCR was performed at an annealing temperature of $60{ }^{\circ} \mathrm{C}$ using the following primers for SSTR1, 2, 3 and 5:

SSTR 1: 5'-GCTACGTGCTCATCATTGCTA-3'; 5'GGACTCCAGGTTCTCAGGTTG-3', product 401 bp

SSTR2: 5'-TTGGTACACAGGGTTCATCAT-3'; 5'GTCTCCGTGGTCTCATTCAGC-3', product $459 \mathrm{bp}$

SSTR 3: 5'-CTGGGTAACTCGCTGGTCAT-3'; 5'-CAGG-

CAGAATATGCTGGTGC-3', product $225 \mathrm{bp}$

SSTR 5: 5'-TCATCTGCCTGTGCTACCTG-3'; 5'-GGAGAGGATGACCACGAAGA-3', product $233 \mathrm{bp}$

Positive controls for the PCRs were carried out using a cDNA from a somatotroph adenoma expressing SSTR1, 2, 3 and 5. SSTR PCR bands were compared to the expression of house-keeping gene gylceraldehyde3-phosphate dehydrogenase (18).

\section{Investigation of the effect of in vivo octreotide treatment on p27 staining in somatotrophinomas}

Histological samples from 25 patients with acromegaly treated for 12 months (range, 2-62 months) with octreotide before transsphenoidal surgery and 23 untreated patients matched for sex, age, tumour size, extension and invasiveness were available for analysis (19). Clinical characteristics, proliferative (Ki-67) and apoptotic indices in this cohort have been described previously (19). Pathological sections underwent immunostaining for p27 and the details of the assessment of p27 staining have been described earlier (12). All the slides were counted by two observers blinded to the diagnosis. All patients involved in the study gave written informed consent and the study was approved by the local Institutional Review Board.

\section{Statistical analysis}

Statistical analysis was performed using the one-way ANOVA test followed by the Newman-Keuls comparison or the Kruskal-Wallis test followed by Conover-Inman comparison, the Mann-Whitney test and the Spearman correlation test (StatsDirect, Cambridge, UK); statistical significance was taken at $P<0.05$, data are expressed as mean \pm s.e.M.

\section{Results}

\section{Cell proliferation in GH3 cells}

SST, octreotide and SOM230 treatment of GH3 cells showed a significant reduction of cell proliferation using the $\left[{ }^{3} \mathrm{H}\right]$-thymidine incorporation assay (Fig. 1). Based on our time $(24,48,72$ and $96 \mathrm{~h})$ and dose-response $\left(10^{-6}-10^{-12} \mathrm{M}\right)$ curves, for further studies, we selected 72-h incubation and the concentrations for each analogue showing the highest levels of inhibition $\left(57.7 \pm 9.9 \%\right.$ control at $10^{-9} \mathrm{M}$ for octreotide and $62 \pm 4.2 \%$ of control at $10^{-6} \mathrm{M}$ for SOM230).

\section{pERK expression in GH3 cells}

Cells treated with octreotide and SOM230 showed a reduction of pERK $1 / 2$ expression in GH3 cells (octreotide, $50 \pm 1.7 \%$ control; SOM230, $61 \pm 6 \%$ control; $P<$ 0.05 compared to control), while PMA showed the expected stimulation $(139 \pm 3 \%$ control; $P<0.05)$. The co-administration of PMA and SST analogues showed a strong inhibitory effect of both analogues on pERK expression (PMA + octreotide, 54 \pm 7\% control; PMA+ SOM230, $76 \pm 20 \%$ control; $P<0.01$ when compared to PMA alone) (Fig. 2).

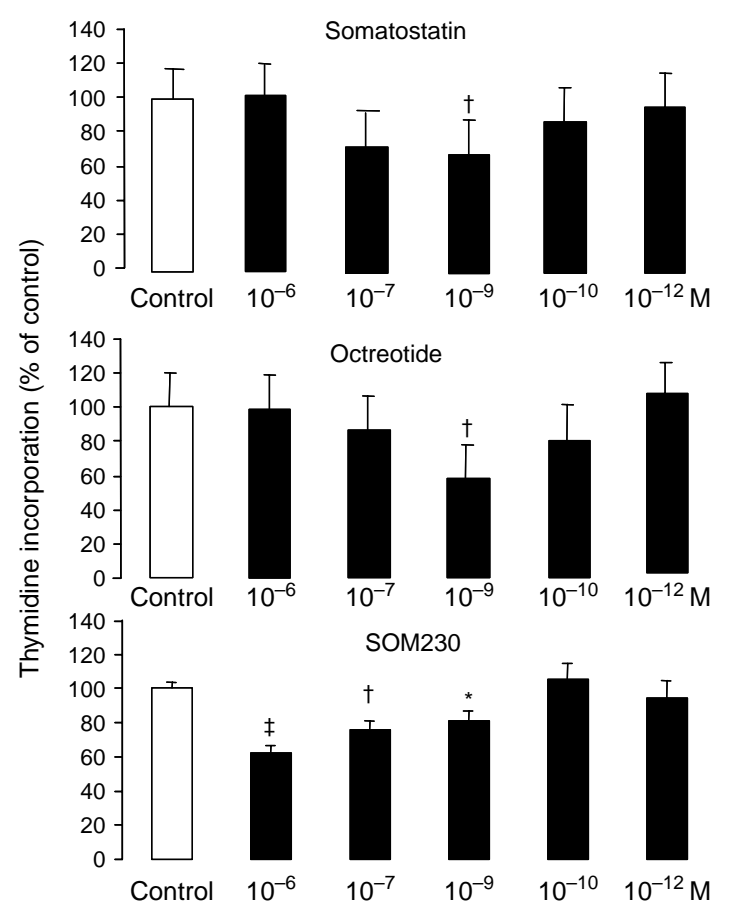

Figure 1 Dose-response curve of somatostatin, octreotide and SOM230 using the $\left[{ }^{3} \mathrm{H}\right]$-thymidine incorporation test for $\mathrm{GH} 3$ cells. ${ }^{\star} P<0.05,{ }^{\dagger} P<0.01,{ }^{\ddagger} P<0.001$ vs control. 


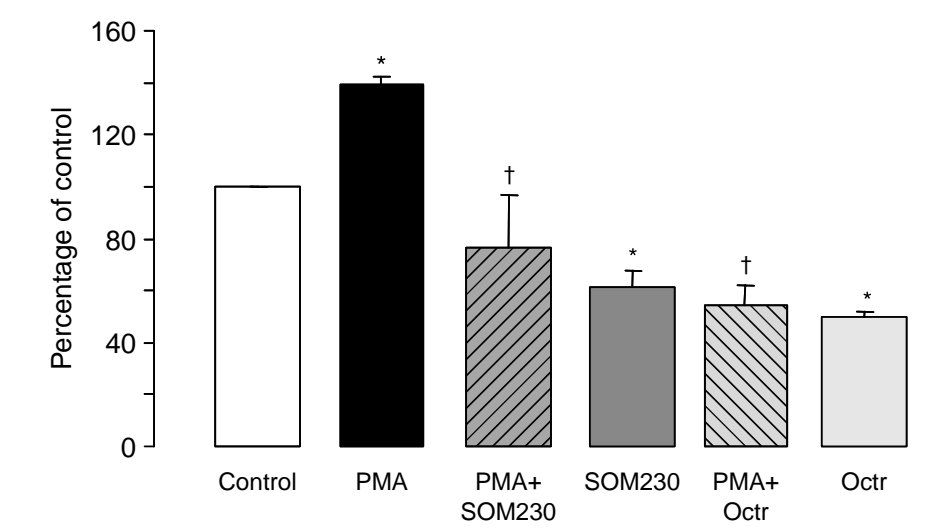

$\mathrm{pERK} 1 / 2$

Total ERK

Figure 2 Effect of 10-min octreotide $\left(10^{-9} \mathrm{M}\right)$, SOM230 $\left(10^{-6} \mathrm{M}\right)$ and 12-phorbol 13-myristate acetate (PMA) $\left(10^{-7} \mathrm{M}\right)$ treatment on ERK1/2 phosphorylation (pERK1/2) in GH3 cells. The ratio of pERK1/2 and total ERK is expressed as percentage of control. ${ }^{\star} P<0.01$ vs control $+P<0.01$ vs PMA.

\section{p27 expression in human pituitary adenomas in response to SST analogues in vitro}

Both octreotide and SOM230 caused a significant increase in p27 protein levels compared to cells treated with media alone $(255 \pm 43$ and $213 \pm 19 \%$ control respectively; $P<0.001)$. Figure $3 \mathrm{~A}$ shows the results according to adenoma types and Fig. $3 \mathrm{~B}$ is a representative immunoblot. The SSTR mRNA expression pattern of the human pituitary adenomas is shown in Table 1; gene transcript expression was comparable in various samples.

\section{pERK expression in human pituitary adeno- mas in response to SST analogues in vitro}

pERK1/2 levels decreased significantly after both octreotide $(60 \pm 8 \%$ control; $P<0.01)$ and SOM $230(59 \pm 7 \%$ vs control; $P<0.01)$ treatment. PMA $\left(10^{-7} \mathrm{M}\right.$; known to activate the PKC-ERK pathway) caused the expected increase in ERK1/2 phosphorylation ( $324 \pm 37 \%$ control; $P<0.001)$, while co-treatment with PMA and SST analogues caused a significant inhibition of pERK activation (PMA + octreotide, $87 \pm 19 \%$ control and PMA+SOM230, $88 \pm 22 \%$ control; $P<0.01$ for both). Figure 4 shows the results according to adenoma types, while Fig. 4B shows a representative immunoblot.

\section{The effect of preoperative octreotide treatment on p27 staining in somatotrophinomas}

We studied nuclear p27 immunostaining of the previously carefully described (19) cohort of adenoma samples obtained from 25 acromegalic patients treated for a median of 12 months (range, 2-62) with octreotide before transsphenoidal surgery and from 23 untreated patients matched for sex, age, tumour size, extension and invasiveness. Octreotide-treated patients showed a significant decrease in their growth hormone

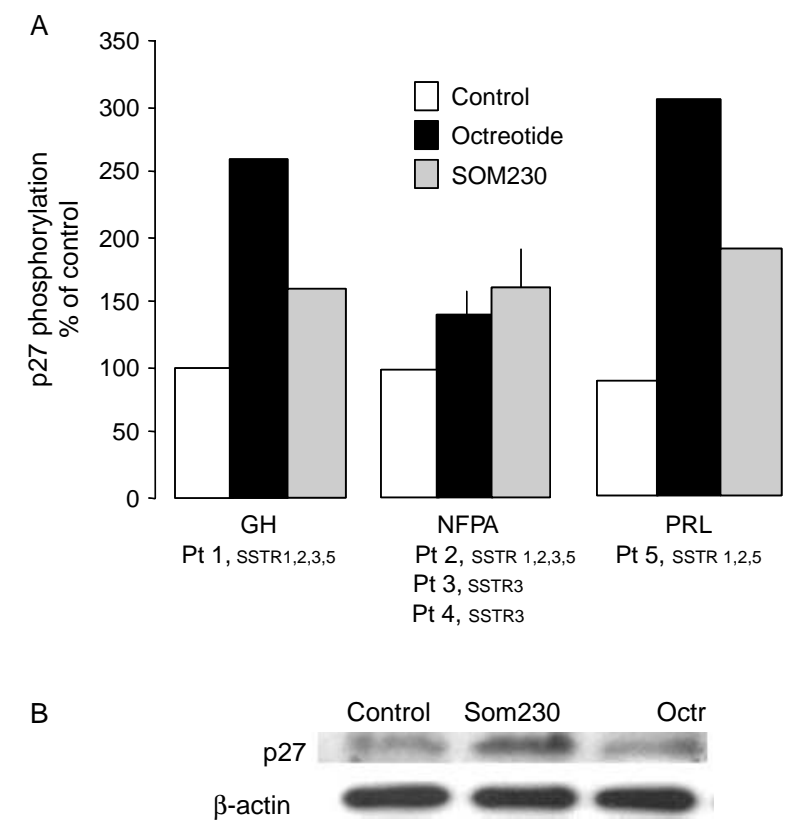

Figure 3 (A) Human pituitary adenomas (somatotroph adenoma, $\mathrm{GH}$, non-functioning adenoma, NFPA and prolactinoma, PRL) were cultured in vitro. The SSTR subtype expression of individual samples (patient (Pt) 1-5) is shown. The effect of octreotide and SOM230 treatment on p27 expression is shown as the ratio of band density of p27 to $\beta$-actin (percentage of control; S.E.M. is shown for the middle panel). (B) Representative blot from the sample of patient 2. 


\section{A}
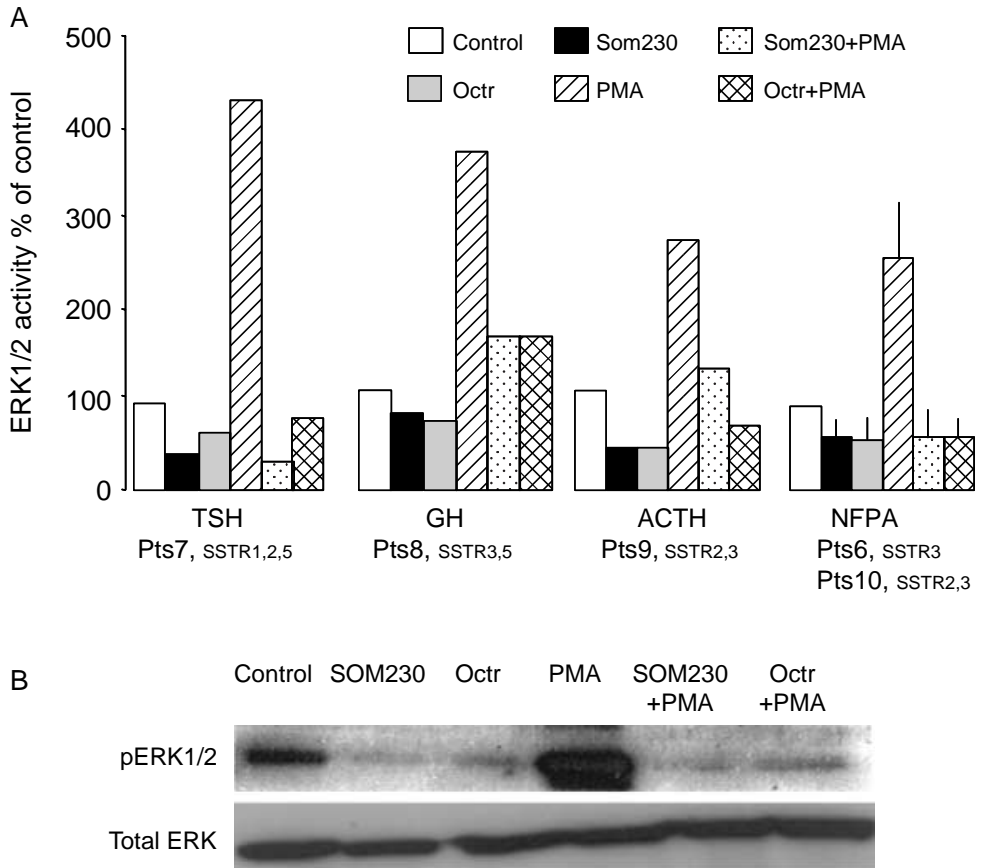

Figure 4 (A) The effect of 10-min in vitro octreotide, SOM230 and PMA treatment is presented in cultured human pituitary adenoma cells (TSH, thyrotrophinoma; GH, somatotroph adenoma; ACTH, corticotrophinoma; NFPA, non-functioning pituitary adenoma). Immunoblotting for phosphorylated ERK1/2 is shown as the ratio to total ERK (percentage of control, S.E.M. is shown for the last panel). (B) Representative blot from patient 7 .

(GH)/insulin-like growth factor-I levels (see detailed data in (19)). No significant difference in p27 staining was observed between the octreotide-treated and untreated groups overall (percentage of cells showing p27-positive staining, median $81 \%$ (range, 9-96\%) vs $58 \%$ (range, $6-100 \%$; $P>0.05$ ), although octreotidetreated patients showed a lower Ki-67 staining (1.8土 $0.3 \%)$ compared to untreated patients $(3.8 \pm 0.7 \% ; P<$ 0.05)) (19). The p27 staining was predominantly nuclear, as previously reported, and the occasional diffuse cytoplasmic staining did not reveal any further differences between the groups $(20,21)$. We also studied the correlation between Ki-67 and p27 staining: in the octreotide-treated group this showed a negative trend with $R=-0.4, P=0.07$. However, when we divided the octreotide-treated patient group into those who had been treated for more or less than 6 months $(n=13$ and 11 respectively), patients with longer than 6 months' octreotide treatment showed significantly higher p27 staining than patients with shorter treatment periods (Fig. 5, $P<0.05$ ). We had 25 pre- and post-treatment MRIs available for the treatment group, with four cases showing more than $20 \%$ tumour shrinkage. These four patients had been treated for more than 6 months with octreotide (range, 8-27 months) and their tumours showed a relatively high p27 $(73 \pm 11 \%)$ and a low Ki67 staining $(0.6 \pm 0.2 \%)$, as compared to those patients showing less shrinkage.

\section{Discussion}

We report that cell proliferation in the rat pituitary GH3 cell line is inhibited by the SST analogues, octreotide and SOM230, and this occurs in parallel with inhibition of ERK1/2 phosphorylation. In GH3 cells, the p27 gene is not expressed due to the methylation of the promoter (22), so we were unable to explore its modulation in this model system. In human pituitary adenomas, we have shown that despite their variable expression of SSTRs, they all show a response to SST agonist stimuli, with

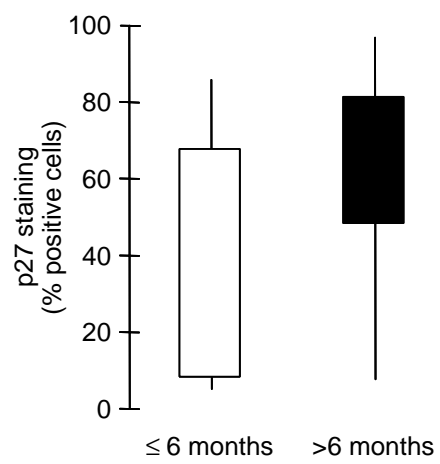

Figure 5 Analysis of p27 staining in patients treated for less than or more than 6 months with octreotide before transsphenoidal surgery for pituitary adenoma. Data are expressed as lower and upper quartiles, and minima and maxima. $P<0.05$ between groups. 
both inhibition of pERK expression and increased expression of p27. p27 expression increased in all the adenomas to at least $150 \%$ of control, while basal unstimulated pERK decreased to at least $80 \%$ or less of control and to $50 \%$ or less of PMA-stimulated samples by octreotide and/or SOM230. This indicates that these parameters significantly change in response to SST analogue treatment in a range of pituitary adenomas. In the clinical study, while octreotide treatment was not obviously associated with an increase in p27 expression overall, long-term treatment ( $>6$ months) positively correlated with an increase in p27 expression. The trend for a negative correlation between p27 and Ki-67 in SST analogue-treated samples supports this hypothesis.

In vitro treatment of human NFPAs with octreotide or lanreotide inhibits cell proliferation $(23,24)$ and octreotide has been shown to induce G0/G1 cell-cycle arrest and thus prevent DNA synthesis in rat GH3 cells (25), but changes in the p27 and the MAP kinase pathways in response to SST analogues have not been previously investigated in pituitary adenomas, despite the fact that pituitary adenomas are one of the primary treatment targets of SST analogues. We have shown previously that normal somatotroph cells contain more p27 protein than somatotroph adenoma cells: for example, $75 \%$ of somatotroph cells in the normal pituitary show positive immunostaining for p27, while somatotroph cells in adenomas show only 40\% p27 staining (26). This staining is predominantly nuclear, where it is considered that p27 acts as a Cdk inhibitor to modulate cell proliferation. The effect of SST on p27 has previously been studied in other cell types (6,27-29). In our study, both octreotide and SOM230 significantly increased p27 expression in human adenomas, and, while the sample size is small, the expression of the distribution of SSTRs in pituitary adenomas appeared to influence the response to the analogues (Fig. 3 and 4). Previous studies have indicated that all SSTRs (other than SSTR4) may be involved in the inhibition of cell proliferation (30). However, octreotide only demonstrates specific binding with high affinity to the SSTR2 and, to a lesser extent, the SSTR 3 and SSTR 5 subtypes $(31,32)$. The recently described new SST analogue, SOM230, now known as pasireotide, has a wider spectrum of activity, with significant binding to SSTR1, 2, 3 and 5 subtypes; affinity to SSTR1 is 30 times that of octreotide, to SSTR 3 times and for SSTR 5 50 times $(3,4)$. It also has a much longer half-life and causes less desensitisation (3), both accounting for the differences seen in the shape of the dose-response curve. It may be that the differential responsiveness to SOM230 and octreotide is related to different and selective receptor expression, but further studies in this area, possibly using techniques such as RNA interference, will be helpful.

The effect of SST on cell proliferation occurs through multiple direct and indirect mechanisms. SST limits cell growth by inhibiting the release of growth factors such as hormones and cytokines, via inhibition of angiogenesis, and several studies describe a strong effect on apoptosis. Apoptosis plays a crucial role in the proliferation and turnover of cells in various malignant tumours and downregulation of p27 may be the main cause of cell differentiation dysfunction and an attenuation of apoptosis. p27 can induce apoptosis of human gastric cancer cells in vitro (33) and p27 can modulate Akt stability, cell survival and tumourigenicity in human breast carcinomas (33). A new molecular pathway for p27 action has been described recently: octreotide induces expression of the tumour suppressor gene Zac1 (34); Zac1 also induces cell-cycle arrest and apoptosis and is highly expressed in normal pituitary, mammary and ovarian glands, but is downregulated in pituitary, breast and ovarian tumours. Zac1 is a target of the phosphatidylinositol 3-kinase (PI3K) survival pathway. Besides the involvement of p27 and MAP kinase pathways, stimulation of tyrosine phosphatase activity may also mediate part of the anti-proliferative effect of SST. In one study, octreotide treatment decreased the tyrosine phosphorylation levels of the PI3K regulatory subunit p85, induced dephosphorylation of phosphoinositide-dependent kinase 1 and Akt, and activated glycogen synthase kinase $3 \beta$ (34).

In vitro studies on human cells studying pituitary hormone secretion used $10^{-8} \mathrm{M}$ concentrations and showed inhibition of GH, thyrotrophin (TSH) and $\alpha$-subunit release, with octreotide having a stronger effect than SOM230 (35-37). However, the maximal effective dose of SST analogues could be different for hormone release and anti-proliferative effects. In cases where the SSTR2 is the most important of the receptor subtypes mediating an effect, SOM230 is an order of magnitude less effective than octreotide. For example, inhibition of ghrelin secretion by octreotide and SOM230 in rats is mainly via SSTR2, so SOM230 requires a higher dose to have the same effect as octreotide (30 vs $3 \mu \mathrm{g} / \mathrm{kg}$ ) (38). In another study, SOM230 generally showed a lower potency for the inhibition of GH release, compared with octreotide (36). In humans, $250 \mu \mathrm{g}$ SOM230 induced a significantly greater suppressive effect on circulating $\mathrm{GH}$ secretion than the $100 \mu \mathrm{g}$ dosage of SOM230, while the inhibitory effect of octreotide $(100 \mu \mathrm{g})$ on $\mathrm{GH}$ levels was equivalent to SOM230 (250 $\mu \mathrm{g})(39)$. This may also explain the lower potency of SOM230 compared to octreotide in patients with acromegaly. The test drug concentration levels, at which half of the maximum drug effect is observed (EC50), are 46 and $553 \mathrm{pg} / \mathrm{ml}$ for octreotide and SOM230 with considerable interpatient variability, mainly attributable to the heterogeneous responses among acromegalic patients (40). Although the overall effects of octreotide and SOM230 on the stimulation of p27 and inhibition of pERK1/2 were not significantly different in our human samples, the variable effects of octreotide and SOM230 on the individual human samples can be explained by several 
mechanisms. The level of receptor expression in each tumour for each receptor subtype is different and, in addition, Jaquet and colleagues observed that SSTR mRNA levels do not directly correlate with SSTR protein levels (41). SST and its analogues could produce homoor heterodimerisation of the SSTR 2 and 5 subtypes resulting in an increased binding affinity and effects in tissue where both are expressed $(42,43)$. There are considerable differences in receptor expression pattern and the activity of octreotide in rat and human SSTR 5 (160-fold greater affinity for the rat SSTR5 (44)), and therefore it may be incorrect to simply extrapolate potency estimates in rodents to human tissue. In addition, there are definite differences in SSTR subtype expression in different types of pituitary adenoma (Table 1). The high expression levels of SSTR2 in GH3 cells may explain the higher efficacy of the SSTR2 preferring agonist octreotide in our rat cells. SOM230 inhibits cell proliferation at concentrations of $10^{-7}$ and $10^{-6} \mathrm{M}$, but not at concentrations $10^{-8}$ and $10^{-9} \mathrm{M}$ in human umbilical vein endothelial cells expressing SSTR 1, -2 and -5 (45). Octreotide was only effective at a $10^{-6} \mathrm{M}$ dose in a recent in vitro study (34), again suggesting that the pharmacological data do not always translate into efficacy in cell systems under the same conditions.

Independent of the effects of SST analogues on hormone secretion, tumour shrinkage has been observed after long-term SST analogue treatment, particularly in somatotroph tumours, usually of the order of $\sim 50 \%$ (46-48). Morphological changes, especially perivascular fibrosis, have been noted in histological studies. Tumour shrinkage has also been reported in $50 \%$ of cases during octreotide treatment in patients with TSH-secreting pituitary adenomas (49), as well as in a very limited number of NFPAs during longterm SST analogue treatment (50). The mechanism of these effects is poorly understood, but regulation of apoptosis, as mentioned above, may be involved. In our samples, as a group, octreotide did not significantly increase p27 staining in somatotroph tumours, although it was associated with a reduction in Ki-67 staining.

In clinical studies, shrinkage is usually evident within 3 months of SST analogue therapy, although further responsiveness over a longer duration is possible (48). Indeed, there are long-term data, which suggest that the anti-proliferative effects of SST analogues may be mediated, at least in part, by p27-induced inhibition of the cell cycle (51).

In conclusion, this study demonstrates that SSTmediated growth inhibition is associated with the downregulation of pERK and upregulation of p27. More potent and broader-spectrum SST analogues are likely to play an increasing role in the treatment of tumours where the MAP kinase pathway is overactivated.

\section{Acknowledgements}

E H was supported by the Royal Society and the Hungarian Endocrine Society. M K was supported by the MRC. MIG was supported by a Hungarian National Research grant (OTKA/2007). We are grateful for Novartis for supplying the octreotide and SOM230.

\section{References}

1 Ezzat S, Asa SL, Couldwell WT, Barr CE, Dodge WE, Vance ML \& McCutcheon IE. The prevalence of pituitary adenomas: a systematic review. Cancer 2004101 613-619.

2 Reubi JC \& Laissue JA. Multiple actions of somatostatin in neoplastic disease. Trends in Pharmacological Sciences 199516 110-115.

3 Bruns C, Lewis I, Briner U, Meno-Tetang G \& Weckbecker G. SOM230: a novel somatostatin peptidomimetic with broad somatotropin release inhibiting factor (SRIF) receptor binding and a unique antisecretory profile. European Journal of Endocrinology $2002146707-716$.

4 Weckbecker G, Briner U, Lewis I \& Bruns C. SOM230: a new somatostatin peptidomimetic with potent inhibitory effects on the growth hormone/insulin-like growth factor-I axis in rats, primates, and dogs. Endocrinology $20021434123-4130$.

5 Cattaneo MG, Taylor JE, Culler MD, Nisoli E \& Vicentini LM. Selective stimulation of somatostatin receptor subtypes: differential effects on Ras/MAP kinase pathway and cell proliferation in human neuroblastoma cells. FEBS Letters $2000 \mathbf{4 8 1}$ 271-276.

6 Pages P, Benali N, Saint-Laurent N, Esteve JP, Schally AV, Tkaczuk J, Vaysse N, Susini C \& Buscail L. sst 2 somatostatin receptor mediates cell cycle arrest and induction of p27(Kip1). Evidence for the role of SHP-1. Journal of Biological Chemistry $1999 \mathbf{2 7 4}$ 15186-15193.

7 Polyak K, Lee MH, Erdjument-Bromage H, Koff A, Roberts JM, Tempst $\mathrm{P} \&$ Massague J. Cloning of $\mathrm{p} 27^{\mathrm{Kip} 1}$, a cyclin-dependent kinase inhibitor and a potential mediator of extracellular antimitogenic signals. Cell 199478 59-66.

8 Nakayama K, Ishida N, Shirane M, Inomata A, Inoue T, Shishido N, Horii I \& Loh DY. Mice lacking p27(Kip1) display increased body size, multiple organ hyperplasia, retinal dysplasia, and pituitary tumors. Cell 199685 707-720.

9 Kiyokawa H, Kineman RD, Manova-Todorova KO, Soares VC, Hoffman ES, Ono M, Khanam D, Hayday AC, Frohman LA \& Koff A. Enhanced growth of mice lacking the cyclin-dependent kinase inhibitor function of p27(Kip1). Cell $1996 \mathbf{8 5} 721-732$.

10 Fero ML, Rivkin M, Tasch M, Porter P, Carow CE, Firpo E, Polyak K, Tsai LH, Broudy V, Perlmutter RM, Kaushansky K \& Roberts JM. A syndrome of multiorgan hyperplasia with features of gigantism, tumorigenesis, and female sterility in p27(Kip1)-deficient mice. Cell $199685733-744$.

11 Bamberger CM, Fehn M, Bamberger A-M, Ludecke D, Beil FU, Saeger W \& Schulte HM. Reduced expression levels of the cell-cycle inhibitor p $27^{\text {Kip } 1}$ in human pituitary adenomas. European Journal of Endocrinology $1999140250-255$.

12 Lidhar K, Korbonits M, Jordan S, Khalimova Z, Kaltsas G, Lu X, Clayton RN, Jenkins PJ, Monson JP, Besser GM, Lowe DG \& Grossman AB. Low expression of the cell cycle inhibitor p $27^{\mathrm{Kip} 1}$ in normal corticotroph cells, corticotroph tumors, and malignant pituitary tumors. Journal of Clinical Endocrinology and Metabolism $1999843823-3830$.

13 Qian X, Jin L, Grande JP \& Lloyd RV. Transforming growth factorbeta and p27 expression in pituitary cells. Endocrinology 1996 137 3051-3060.

14 Theodoropoulou M, Arzberger T, Gruebler Y, Jaffrain-Rea ML, Schlegel J, Schaaf L, Petrangeli E, Losa M, Stalla GK \& Pagotto U. 
Expression of epidermal growth factor receptor in neoplastic pituitary cells: evidence for a role in corticotropinoma cells. Journal of Endocrinology 2004183 385-394.

15 Komatsubara K, Tahara S, Umeoka K, Sanno N, Teramoto A \& Osamura RY. Immunohistochemical analysis of p27 (Kip1) in human pituitary glands and in various types of pituitary adenomas. Endocrine Pathology 200112 181-188.

16 Takeuchi S, Koeffler HP, Hinton DR, Miyoshi I, Melmed S \& Shimon I. Mutation and expression analysis of the cyclin-dependent kinase inhibitor gene p27/Kip1 in pituitary tumors. Journal of Endocrinology $1998157337-341$.

17 Nanzer AM, Khalaf S, Mozid AM, Fowkes RC, Patel MV, Burrin JM, Grossman AB \& Korbonits M. Ghrelin exerts a proliferative effect on a rat pituitary somatotroph cell line via the mitogen-activated protein kinase pathway. European Journal of Endocrinology 2004 $151233-240$.

18 Korbonits M, Chitnis MM, Gueorguiev M, Norman D, Rosenfelder N, Suliman M, Jones TH, Noonan K, Fabbri A, Besser GM, Burrin JM \& Grossman AB. The release of leptin and its effect on hormone release from human pituitary adenomas. Clinical Endocrinology 200154 781-789.

19 Losa M, Ciccarelli E, Mortini P, Barzaghi R, Gaia D, Faccani G, Papotti M, Mangili F, Terreni MR, Camanni F \& Giovanelli M. Effects of octreotide treatment on the proliferation and apoptotic index of GH-secreting pituitary adenomas. Journal of Clinical Endocrinology and Metabolism 200186 5194-5200.

20 Lidhar K, Korbonits M, Jordan S, Khalimova Z, Kaltsas G, Lu X, Clayton RN, Jenkins PJ, Monson JP, Besser GM, Lowe DG \& Grossman AB. Low expression of the cell cycle inhibitor $\mathrm{p} 27^{\mathrm{Kip} 1}$ in normal corticotroph cells, corticotroph tumors, and malignant pituitary tumors. Journal of Clinical Endocrinology and Metabolism 199984 3823-3830.

21 Korbonits M, Chahal HS, Kaltsas G, Jordan S, Urmanova Y, Khalimova Z, Harris PE, Claret FX \& Grossman AB. Expression of phosphorylated p $27^{\mathrm{Kip} 1}$ protein and Jab1 (Jun activation domainbinding protein 1) in human pituitary tumors. Journal of Clinical Endocrinology and Metabolism 200287 2635-2643.

22 Qian X, Jin L, Kulig E \& Lloyd RV. DNA methylation regulates p27kip1 expression in rodent pituitary cell lines. American Journal of Pathology 1998153 1475-1482.

23 Florio T, Thellung S, Arena S, Corsaro A, Spaziante R, Gussoni G, Acuto G, Giusti M, Giordano G \& Schettini G. Somatostatin and its analog lanreotide inhibit the proliferation of dispersed human non-functioning pituitary adenoma cells in vitro. European Journal of Endocrinology 1999141 396-408.

24 Renner U, Mojto J, Lange M, Muller OA, von Werder K \& Stalla GK. Effect of bromocriptine and SMS 201-995 on growth of human somatotrophic and non-functioning pituitary adenoma cells in vitro. European Journal of Endocrinology 1994130 80-91.

25 Cheung NW \& Boyages SC. Somatostatin-14 and its analog octreotide exert a cytostatic effect on $\mathrm{GH} 3$ rat pituitary tumor cell proliferation via a transient G0/G1 cell cycle block. Endocrinology $19951364174-4181$.

26 Korbonits M, Chahal HS, Kaltsas G, Jordan S, Urmanova Y, Khalimova Z, Harris PE, Claret FX \& Grossman AB. Expression of phosphorylated p $27^{\text {Kip1 }}$ protein and Jab1 (Jun activation domainbinding protein 1) in human pituitary tumors. Journal of Clinical Endocrinology and Metabolism 200287 2635-2643.

27 Medina DL, Velasco JA \& Santisteban P. Somatostatin is expressed in FRTL- 5 thyroid cells and prevents thyrotropin-mediated downregulation of the cyclin-dependent kinase inhibitor p $27^{\text {Kip1 }}$. Endocrinology 1999140 87-95.

28 Fisher WE, Wu Y, Amaya F \& Berger DH. Somatostatin receptor subtype 2 gene therapy inhibits pancreatic cancer in vitro. Journal of Surgical Research 2002105 58-64.

29 Celinski SA, Fisher WE, Amaya F, Wu YQ, Yao Q, Youker KA \& Li M. Somatostatin receptor gene transfer inhibits established pancreatic cancer xenografts. Journal of Surgical Research 2003 $11541-47$.

30 Benali N, Ferjoux G, Puente E, Buscail L \& Susini C. Somatostatin receptors. Digestion 200062 (Suppl 1) 27-32.
31 Buscail L, Esteve JP, Saint-Laurent N, Bertrand V, Reisine T, O'Carroll AM, Bell GI, Schally AV, Vaysse N \& Susini C. Inhibition of cell proliferation by the somatostatin analogue RC-160 is mediated by somatostatin receptor subtypes SSTR2 and SSTR5 through different mechanisms. PNAS $1995 \mathbf{9 2}$ 1580-1584.

32 Reubi JC, Lang W, Maurer R, Koper JW \& Lamberts SW. Distribution and biochemical characterization of somatostatin receptors in tumors of the human central nervous system. Cancer Research $1987475758-5764$.

33 Zhu JS, Wang L, Cheng GQ, Li Q, Zhu ZM \& Zhu L. Apoptosis mechanisms of human gastric cancer cell line MKN-45 infected with human mutant p27. World Journal of Gastroenterology 2005 $117536-7540$.

34 The odoropoulou M, Zhang J, Laupheimer S, Paez-Pereda M, Erneux C, Florio T, Pagotto U \& Stalla GK. Octreotide, a somatostatin analogue, mediates its antiproliferative action in pituitary tumor cells by altering phosphatidylinositol 3-kinase signaling and inducing Zac1 expression. Cancer Research 200666 1576-1582.

35 Murray RD, Kim K, Ren SG, Lewis I, Weckbecker G, Bruns C \& Melmed S. The novel somatostatin ligand (SOM230) regulates human and rat anterior pituitary hormone secretion. Journal of Clinical Endocrinology and Metabolism 200489 3027-3032.

36 Hofland LJ, van der Hoek J, van Koetsveld PM, de Herder WW, Waaijers M, Sprij-Mooij D, Bruns C, Weckbecker G, Feelders R, van der Lely AJ, Beckers A \& Lamberts SW. The novel somatostatin analog SOM230 is a potent inhibitor of hormone release by growth hormone- and prolactin-secreting pituitary adenomas in vitro. Journal of Clinical Endocrinology and Metabolism 200489 1577-1585.

37 van der Hoek J, Waaijers M, van Koetsveld PM, Sprij-Mooij D, Feelders RA, Schmid HA, Schoeffter P, Hoyer D, Cervia D, Taylor JE, Culler MD, Lamberts SW \& Hofland LJ. Distinct functional properties of native somatostatin receptor subtype 5 compared with subtype 2 in the regulation of ACTH release by corticotroph tumour cells. American Journal of Physiology-Endocrinology and Metabolism 2005289 E278-E287.

38 Silva AP, Bethmann K, Raul F \& Schmid HA. Regulation of ghrelin secretion by somatostatin analogs in rats. European Journal of Endocrinology $2005152887-894$.

39 van der Hoek J, de Herder WW, Feelders RA, van der Lely AJ, Uitterlinden P, Boerlin V, Bruns C, Poon KW, Lewis I, Weckbecker G, Krahnke T, Hofland LJ \& Lamberts SW. A single-dose comparison of the acute effects between the new somatostatin analog SOM230 and octreotide in acromegalic patients. Journal of Clinical Endocrinology and Metabolism 200489 638-645.

40 Ma P, Wang Y, van der HJ, Nedelman J, Schran H, Tran LL \& Lamberts SW. Pharmacokinetic-pharmacodynamic comparison of a novel multiligand somatostatin analog, SOM230, with octreotide in patients with acromegaly. Clinical Pharmacology and Therapy 200578 69-80.

41 Jaquet P, Saveanu A, Gunz G, Fina F, Zamora AJ, Grino M, Culler MD, Moreau JP, Enjalbert A \& Ouafik LH. Human somatostatin receptor subtypes in acromegaly: distinct patterns of messenger ribonucleic acid expression and hormone suppression identify different tumoral phenotypes. Journal of Clinical Endocrinology and Metabolism 200085 781-792.

42 Rocheville M, Lange DC, Kumar U, Sasi R, Patel RC \& Patel YC. Subtypes of the somatostatin receptor assemble as functional homo- and heterodimers. Journal of Biological Chemistry 2000275 7862-7869.

43 Rocheville M, Lange DC, Kumar U, Patel SC, Patel RC \& Patel YC. Receptors for dopamine and somatostatin: formation of heterooligomers with enhanced functional activity. Science $2000 \mathbf{2 8 8}$ 154-157.

44 Reisine T \& Bell GI. Molecular biology of somatostatin receptors. Endocrine Reviews 199516 427-442.

45 Adams RL, Adams IP, Lindow SW \& Atkin SL. Inhibition of endothelial proliferation by the somatostatin analogue SOM230. Clinical Endocrinology 2004 61 431-436. 
46 Patel YC. Somatostatin and its receptor family. Frontiers of Neuroendocrinology 199920 157-198.

47 Lamberts SWJ, van der Lely AJ, deHerder WW \& Hofland LJ. Octreotide. New England Journal of Medicine $1996 \mathbf{3 3 4}$ 246-254.

48 Bevan JS. Clinical review: the antitumoral effects of somatostatin analog therapy in acromegaly. Journal of Clinical Endocrinology and Metabolism $2005901856-1863$.

49 Beck-Peccoz P, Brucker-Davis F, Persani L, Smallridge RC \& Weintraub BD. Thyrotropin-secreting pituitary tumors. Endocrine Reviews 199917 610-638.

50 Colao A, Filippella M, Di Somma C, Manzi S, Rota F, Pivonello R, Gaccione M, De Rosa M \& Lombardi G. Somatostatin analogs in treatment of non-growth hormone-secreting pituitary adenomas. Endocrine $200320279-283$.

51 Viglietto G, Motti ML, Bruni P, Melillo RM, D’Alessio A, Califano D, Vinci F, Chiappetta G, Tsichlis P, Bellacosa A, Fusco A \& Santoro M. Cytoplasmic relocalization and inhibition of the cyclin-dependent kinase inhibitor p27(Kip1) by PKB/Akt-mediated phosphorylation in breast cancer. Nature Medicine 20028 1136-1144.

Received 3 January 2006

Accepted 24 May 2006 